\title{
Is Saul also among the Prophets?*
}

\author{
By George Rosen, ** New York \\ David Feigns Madness
}

When David broke with Saul after the latter tried to kill him, he first fled south into Judea. Then recognizing his inability to withstand the royal power, David decided to seek refuge elsewhere. As a possible haven he turned to Achish the Philistine, king of Gath, the city from which Goliath had come. According to one version of this event, David, uncertain of the reception which he, a former enemy, might receive, resorted to a ruse and pretended to be mad, "So he changed his behavior before them [the Philistines]," we are told, "and feigned himself mad in their hands, and made marks on the doors of the gate, and let his spittle run down his beard. Then said Achish to his servants, 'Lo, you see the man is mad; why then have you brought him to me? Do I lack madmen, that you have brought this fellow to play the madman in my presence?" 1

This episode as well as other passages in the Old Testament show clearly that mental disorders occurred and were recognized as such among the ancient Hebrews and the peoples who were their neighbors. Although the incidence or prevalence of such conditions cannot be known, the available information does permit the delineation of certain forms of psychopathology, of ideas concerning their causation, and of the ways in which those afflicted with these conditions were regarded and dealt with by the community. In this connection, the story of Saul, the first king of Israel (reigned ca. $1020-1000$ B. c.) is of particular interest, because more detailed information than usual is available about him.

\section{Is Saul Also Among the Prophets?}

The need for unified leadership felt by the Israelite tribes in meeting the attacks of neighboring peoples (Ammonites, Philistines, Amalekites) led them to give up their earlier organization as a tribal confederacy and to

* This paper is part of a larger study on the historical sociology of mental illness supported by grant M-3171 of the National Institutes of Health.

** Columbia University, School of Public Health and Administrative Medicine.

1 I Samuel 21 : 13-15. All biblical quotations, unless otherwise stated are from The Oxford Annotated Bible. The Holy Bible, Revised Standard Version containing the Old and New Testaments... Edited by Herbert G. May and Bruge M. Metzger, Oxford University Press, New York 1962. 
unite under a centralized monarchy. Samuel, the last of the judges, opposed but could not prevent the appointment of a king. To reign over them, the Israelites called Saul, a tribesman of Benjamin, who first came to the fore as a military and political leader by rallying his countrymen to relieve Jabesh-Gilead, besieged by the Ammonites.

At first, Saul acted energetically and decisively; and his rapid initial successes were undoubtedly the consequence of his military and political ability. Yet, Saul seems to have carried in his personality the seeds of his destruction. The saying, "Is Saul also among the prophets?", which became proverbial, hints at a tendency to emotional instability. ${ }^{2}$ Two stories are told to explain the origin of the proverb. In the first of these, Samuel tells the newly anointed Saul of a number of signs confirming his new position, which he will encounter on his homeward way, among them a meeting with a company of prophets whom Saul will join in prophesying. And so it happened. "When they came to Gibeah, behold, a band of prophets met him; and the spirit of God came mightily upon him, and he prophesied among them. And when all who knew him before saw how he prophesied with the prophets, the people said to one another, "What has come over the son of Kish? Is Saul among the prophets?" 3

Another version of the origin of the proverb links it with Saul's attempt to kill David after he began to fear him as a potential rival. With the help of Michal, his wife, David escaped and fled to Samuel at Ramah. Saul pursued him and "came to the great well that is in Secu; and he asked, "Where are Samuel and David?' And one said 'Behold, they are at Naioth in Ramah'. And he went from there to Naioth in Ramah; and the Spirit of God came upon him also, and as he went he prophesied, until he came to Naioth in Ramah. And he too stripped off his clothes, and he too prophesied before Samuel, and lay naked all that day and all that night. Hence it is said, 'Is Saul also among the prophets?" 4

That there are two versions of the origin of this proverbial saying is immaterial. The very existence of two explanations tends to remove any doubt about the fact itself. Saul was among the prophets because he was susceptible to the psychic contagion of group excitation. Both traditions specifically associate him with the bands of ecstatic prophets who appear prominently in Israel's history at the time of Samuel. The behavorial and

2 I Samuel 10: 12; 19:24.

3 I Samuel 10: 10-11.

4 I Samuel 20: 22-24. 
psychologic aspects of prophecy will not be discussed now. Here it is sufficient to point out that by means of music and dancing these groups worked themselves into a frenzy or trance, during which they uttered their prophecies. Experiences of this sort can be induced by a wide range of stimuli, frequently acting at the same time, which produce physiological and psychological stresses.

On both occasions when Saul prophesied he was under strong emotional tension. The oracle communicated by Samuel to Saul, that he had been chosen by the Lord for kingship, and that he would encounter confirmatory signs of this choice, created a state of excitement and expectation in which Saul was prepared to act the prophet, and thus be "turned into another man" qualified to lead Israel. Saul's behavior was conditioned and colored by his expectations, but it is also likely that Samuel recognized him as a man who would readily respond to the excitement and elation of group prophesy. ${ }^{5}$ Indeed, the story of Saul prophesying before Samuel at Ramah offers a hint that he was found among the prophets more often than on the two occasions reported in I Samuel.

Repeated exposure to situations and stimuli that lead to group arousal phenomena tends to sensitize the participants so that they lose contact with their surroundings more and more readily. Moreover, the state of acute excitement and emotional disruption which develops under such circumstances very often ends with collapse in total exhaustion, a condition in which the individual may remain unconscious for varying periods of time, sometimes for hours. ${ }^{6}$

How often Saul experienced such psychological disturbances, and exhibited their physical manifestations is not known. Nonetheless, episodes of this kind must have occurred often enough to impress the popular consciousness that this trait was characteristic of Saul. Moreover, the events at Ramah can also be related to changes in Saul's political situation and

5 Alfred Guillaume, Prophecy and Divination among the Hebrews and other Semites, Hodder and Stoughton, London 1938, p. 300.

6 Maya Deren, Divine Horsemen. The Living Gods of Haiti, Thomas \& Hudson, London/ New York 1953, pp. 250-262, 322-323. The experience of Miss Deren, who in 1949 went to Haiti to study and film Haitian dancing is relevant here. During a Voodoo service she became possessed by Erszulie, the goddess of Love. Subsequently, she experienced seven or eight episodes of possession, and found that she fell into this state with increasing ease. Furthermore, she remained unconscious for varying periods, on one occasion some four hours elapsed before she regained consciousness. 
state of mind that developed earlier. Apparently, the episode at Ramah took place at a time when Saul was already suffering from emotional disturbance. Although the chronology of the biblical text is somewhat uncertain, the outbreak of his illness is brought into direct relationship to a conflict with Samuel.

\section{Saul's Disobedience and Rejection}

The conflict was occasioned by the victory won by Saul in his war (ca. 1016 в. c.) against the Amalekites, a fierce, nomadic people, traditionally descended from Esau, who had long been enemies of the Israelites.? Before the campaign began, Samuel charged Saul in the name of the Lord to extirpate Amalek, to put to the sword "both man and woman, infant and suckling, ox and sheep, camel and ass ". ${ }^{8}$ Despite these instructions, however, Saul, perhaps motivated more by political than religious considerations, did not kill Agag, king of the Amalekites, but took him prisoner. Nor did he destroy all the flocks, but allowed his soldiers to keep some animals as spoils of war, and for sacrificing at the sanctuary of Gilgal. Aroused by these acts, Samuel confronted Saul, denounced his disobedience, and inspired by prophetic wrath pronounced his doom. Implacable and uncompromising in his anger, Samuel withdrew divine support from Saul, saying "you have rejected the word of the Lord, and the Lord has rejected you from being king over Israel... The Lord has torn the kingdom of Israel from you this day, and has given it to a neighbor of yours who is better than you". 9

Kingship as conceived by the Israelites was an expression of God's favor. The king was elected by God, and appointed to his office by the Lord's messenger, the prophet. Although the bearer of God's grace, the monarch's tenure was conditional upon his submission to the will of God. As long as the king obeyed the word of the Lord, he and his kingdom would flourish; disobedience and rebellion ineluctably evoked retribution and ultimately annihilation. ${ }^{10}$

7 Exodus 17: 8-16; Deuteronomy 25: 17-19.

8 I Samuel 15: 1-3.

9 I Samuel 15: 26-28.

10 Yehezkel Kaufmann, The Religion of Israel. From its Beginnings to the Babylonian Exile. Translated and abridged by Moshe Greenberg, University of Chicago Press, Chicago and London 1960, pp. 263-266, 272-273. 
Samuel's defiance and rejection of Saul for his failure to carry out a divine command was thus both a challenge to the monarchy and a warning of punishment to come. Tradition recalled this dramatic conflict and its consequences by presenting the onset of Saul's mental illness within this context. Following the bitter, irreparable quarrel with Samuel, "the Spirit of the Lord departed from Saul, and an evil spirit from the Lord tormented him ".11

\section{Saul and David: A Contest for Power}

The breach with Samuel and the prophetic groups who supported him undoubtedly weighed heavily on Saul's mind and temper, bringing to the surface and intensifying his latent emotional instability. In the light of the profound significance of Samuel's action, it is not surprising that Saul responded as he did. Moreover, Saul's religious and political difficulties were further aggravated by problems that arose at his court and within his own family, notably his quarrel with David, his son-in-law, and his disappointment with his son, Jonathan. The biblical text has retained the essential core of these dramatic relationships and through a number of vivid stories throws a bright light on the personalities involved.

The initial interweaving of the fates of Saul and David apparently occurred at a time when Saul's mental disorder had already become clearly manifest. Saul's attention was first directed to David, a young Judean, member of a prominent family of Bethlehem, when he was advised by his counsellors to secure a skilful musician whose playing would relieve the torments inflicted by the evil spirit from God. ${ }^{12}$ David was celebrated by Israelite tradition as a musician and poet, and his talent became evident, no doubt, at an early age. ${ }^{13}$ By inviting David to enter his service, Saul was probably also endeavoring to further his policy of establishing a firmer union between the men of Judah and the Israelites of central Palestine. ${ }^{\mathbf{1 4}}$

All the relevant traditions describe David as an attractive, engaging figure, possessed of great personal charm, and at first he found favor with the

11 I Samuel 16: 14.

12 I Samuel 16: 15-18.

13 Kaufmann, op.cit., pp. 110, 267-268; W.F.Albright, The Biblical Period from Abraham to Ezra, Harper \& Rowe, New York and Evanston, 1963, pp. 50-51; ib. Archaeology and the Religion of Israel, Johns Hopkins Press, Baltimore 1942, pp.125-129.

14 Elias Auerbach, Wüste und Gelobtes Land, erster Band, Geschichte Israels von den Anfängen bis zum Tode Salomos, Schocken-Verlag, Berlin 1936, p. 196. 
king. Indeed, according to the oldest account of their relationship, Saul's suspicion of David did not become evident until sometime after he had come to the royal court. During this period, David acquired important posts, as the king's armor-bearer and as a military leader, and he became Saul's son-in-law. At the same time, he also established ties of friendship and blood brotherhood with Jonathan, the king's son and his presumptive successor.

As Saul's illness in itself was obviously no hindrance to David's rise, one can hardly assume that the sudden change in his attitude toward David, the suspicion and hostility which he developed to a pathological degree, occurred without any provocation on David's part. Later writers, in order to glorify David and his dynasty, felt it necessary to depreciate Saul and to present David's actions in the most favorable light. Nonetheless, there are tantalizing traces in the biblical text that hint at intrigues and a conspiracy against Saul in which David was involved. Samuel, in pursuing his policy of opposition to Saul, may have entered into relations with David, after he obtained a position of power and influence, thus arousing Saul's suspicion. Certainly, David's flight to Samuel at Ramah after Saul's attempt to assassinate him suggests such a connection. ${ }^{15}$ Moreover, there is evidence also which suggests strongly that Jonathan conspired with David to carry out a palace revolution to remove Saul from the throne. ${ }^{16}$

Whatever the precise course of events may have been Saul began to fear David as a potential rival and determined to kill him. As the conviction grew within him that his former favorite now was his enemy, Saul pursued him with unrelenting obduracy. On one occasion, in an attack of uncontrolled rage he tried unsuccessfully to pierce David with a spear. ${ }^{17}$ After another attempted assassination failed, David fled Saul's court. ${ }^{18}$ The break between them now became an open struggle for political primacy. Driven by an obsessive hatred of David, Saul repeatedly tried to capture him, devoting to this aim energies and resources which might have been more fruitfully applied to other pressing and crucial problems. For Saul's kingdom was still not firmly established. He had defeated the semi-nomadic Ammonites and Amalekites, but the solidly organized Philistine confederation

15 I Samuel 19: 18; see also I Samuel 16: 1-13.

16 Auerbach, op.cit., pp. 198-199; I Samuel 20: 30-31, 22: 7-8.

17 I Samuel 18: 10-11, 19:9-10. The same incident appears to be told twice.

18 I Samuel 19: 11-17. 
loomed as a major menace, and it was in his desperate effort to stem the Philistine advance that catastrophe overwhelmed him.

Yet, even if the political need to neutralize or destroy his enemy is taken into account, Saul's behaviour undoubtedly exhibits an increasingly pathological quality. If stress is severe enough, the most stable personality may show evidence of anger, aggressiveness, anxiety, depression, irritability and excitement. Saul began his career as a popular hero, rising over Israel like a shining star. At first confident and determined, he won important military victories over Israel's enemies, but as the problems which he faced became more difficult and increased in number, his latent susceptibility to psychic disturbance turned into increasingly manifest disorder.

Suspecting treachery on the part of those who served him, and unable to brook opposition, Saul vented his fear and hostility in emotional outbursts associated with uncontrollable impulses, as on the occasion when he lost control of himself and hurled a spear at David, or when he acted similarly toward his son Jonathan. ${ }^{19}$ At other times, Saul became moody and depressed, a condition which apparently recurred more frequently as he proved increasingly unable to cope with his difficulties. In part, perhaps, the attacks of depression and uncontrolled behavior were also an adverse result of the ecstatic seizures which he often experienced. Mental depression, impaired judgment and increased suggestibility may ensue after prolonged indulgence in ecstasy. ${ }^{20}$

Saul's meeting with the medium of Endor provides a striking portrayal of his state of mind on the eve of the battle in which he found a tragic death. ${ }^{21}$ The man who had been a determined and decisive leader now hesitated, unable to decide what course of action to take and depressed by a foreboding of impending doom. Indeed, Saul's resort to necromancy was an act of desperation, the act of a man at the end of his tether. Certain mantic techniques were prohibited by Israelite religion, among these necromancy, and tradition has it that Saul suppressed wizards and mediums. ${ }^{22}$

19 I Samuel 18: 10; 20: 32-33.

20 William Sargant, Battle for the Mind. A Physiology of Conversion and Brain-Washing, Penguin Books, Baltimore (Md.) 1961, pp. 74, 108-109.

21 I Samuel 28: 20-21. The traditional English rendering, the witch of Endor, carries with it connotations and associations that make it inappropriate. The woman of Endor was able to raise the ghosts of Samuel, so that Saul could consult him, in short, for the purpose of necromancy. From this viewpoint, it appears more suitable to refer to her as a medium.

22 Deuteronomy 18: 10-11; Kaufmann, op.cit., pp. 78-93; I Samuel 28: 3. 
Yet when the Lord did not answer his inquiries "either by dreams, or by Urim [i.e. by lots] or by prophets", his feeling of abandonment and isolation led him to resort to the extreme measure of raising the ghost of Samuel so as to learn from him what to do. But this last desperate act brought Saul neither counsel nor hope. The shade of his dead opponent only confirmed his own grim apprehension that he was doomed to defeat and death. Thereupon, "Saul fell at once full length upon the ground filled with fear because of the words of Samuel". ${ }^{23}$ Finally accepting what was to come, he determined "not to flee from it or, by clinging to life, to betray his people to the enemy and dishonour the dignity of kingship; instead, he thought it noble to expose himself, his house and his children to these perils and, along with them, to fall fighting for his subjects". ${ }^{24}$ Thus, on the following day, when the Philistines and the Israelites clashed on Mount Gilboa, Saul fought bravely as long as he could, and committed suicide by falling on his sword, only after three of his sons were killed and he had been severely wounded. ${ }^{25}$

\section{An Evil Spirit From the Lord}

For a number of reasons, the story of Saul, king of Israel, is of more than passing interest. Not only does it provide specific detail about an early case of mental and emotional disorder, but in doing so also offers a causal explanation and describes a form of therapy. Moreover, a consideration of the terminology used to describe Saul's behavior, when taken together with other evidence, enables us to delineate certain social attitudes toward the mentally disordered and to others who appeared to act like them.

The belief that illness was inflicted by a supernatural power or by an angry deity as a punishment for sin was widespread among the peoples of the ancient world. Among the Hebrews, those who presumed to disobey God's commandments and to violate his ordinances were threatened with dire retribution, including the curse of madness. Deuteronomy, which dates from the 7 th century B.c. but rests on ancient tradition, contains a warning by Moses to his people that if they "will not obey the voice of the

23 I Samuel 28: 20.

24 Josephus, with an English translation by H.St.J.Thackeray, Ralph Marcus, and Allen Wikgren, 9 vols., (Loeb Classical Library), Harvard University Press, Cambridge (Mass.); vol.5, William Heinemann, London 1958, p. 341.

25 II Samuel: 1 offers a different version of Saul's death, according to which he was slain by an Amalekite at his request, because he was too weak from his wounds to kill himself as he wished to do. 
Lord your God or be careful to do all his commandments and his statutes... the Lord will smite you with madness and blindness and confusion of mind ...". ${ }^{26}$ Similarly the prophet Zachariah, who lived in the 6 th century B. C., foretells that God will punish those who attack Jerusalem. "On that day, says the Lord, I will strike every horse with panic and its rider with madness". ${ }^{27}$

The origin and onset of Saul's illness is a specific instance of such punishment. Israel's king was regarded as the elect of God, as the bearer of divine grace. The rite of anointing, symbolizing his election, was followed by an outpouring of the divine Spirit upon the chosen one. This viewpoint is clearly reflected in the account of Samuel's selection of David to succeed Saul. "Then Samuel took the horn of oil and anointed him in the midst of his brothers and the Spirit of the Lord came mightily upon David from that day forward". ${ }^{28}$ However, divine election and the associated special endowment with the Spirit were conditional upon the king's continuing submission to the will of God. Rebellion against the divine command annulled his election, removed from him the favor of God, and made him subject to divine wrath. To walk in the ways of the Lord or to be punished by an angry God were the polar alternatives by which Israel's divinely elected king was to guide his actions..$^{29}$ This is the context which gives full meaning to the statement, "the Spirit of the Lord departed from Saul and an evil spirit from the Lord tormented him".

The disorder which befell Saul proceeded from God through a spirit, but beyond this bare statement no details are given in the biblical text. The nature of the spirit which troubled Saul is not specified nor is it endowed with any psychic attributes. In a large number of instances, the term ruach (spirit) is used in the Old Testament to denote a supernatural energy or influence acting on man. ${ }^{30}$ In this case the adjective "evil" differentiates this spirit from the Spirit of the Lord (ruach Y $_{\text {H }}$ ) which occurs in the same sentence.

26 Deuteronomy 28: 15, 28.

27 Zechariah 12: 4.

${ }^{28}$ I Samuel 16: 13; cf. I Samuel 10: 1, 6ff.; 11:6ff.

${ }^{29}$ S.H.Hooke (ed.), Myth.Ritual, and Kingship. Essays on the Theory and Practice of Kingship in the Ancient Near East and in Israel, Clarendon Press, Oxford 1958, pp. 207-211; KaUfMaNN, op.cit., pp.265-272.

30 H. Wheeler Robinson, Inspiration and Revelation in the Old Testament, Clarendon Press, Oxford 1956, p.74. 
Furthermore, subjective symptoms are almost entirely absent in the story of Saul's disorder. The instances in which Saul raged and acted in an uncontrolled manner provide information about his observable behavior, but there is no direct information on his subjective condition when he was tormented. Later writers elaborated on the biblical text by supplying details not contained in it, but which rested perhaps on early traditions. Thus, the Greek version of the Old Testament, the Septuagint, which dates from the 3 rd century B.c., has it that the evil spirit "choked" Saul. ${ }^{31}$ About four centuries later, the historian Josephus (37-38 A.D.-ca. 100 A.D.), in his massive Jewish Antiquities (93-94 A.D.), related that Saul "was beset by strange disorders and evil spirits which caused him such suffocation and strangling that the physicians could devise no other remedy save to order search to be made for one with power to charm away spirits ..." 32 Josephus used Hebrew (or Aramaic) and Greek versions of the biblical text, adding to his account amplifications derived from traditional lore for which parallels exist in other writings.

A significant instance relating to Saul occurs in a work dating from the same period, written by an unknown Jewish contemporary of Josephus. The Biblical Antiquities, as this book is now called, is available only in a Latin translation, made from a Greek version, and that again from a Hebrew original. By accident, the name of PHILo, the Jewish philosopher of the first century, was attached to it when it was first published in $1527 . .^{33}$ This attribution is wholly unfounded, and since the author, possibly a Palestinian Jew, is unknown he has been called Pseudo-Philo for convenience. His work, perhaps modelled on the book of Chronicles, tells the Bible story from the creation of the world to the death of Saul. Significantly, PseudoPhilo in his account of Saul also relates that after his rejection he was choked by an evil spirit. ${ }^{34}$

The version of Saul's illness presented by Josephus and Pseudo-Philo, and the wording employed in the Septuagint, apparently represent an es-

31 The Septuagint Version of the Old Testament, with an English Translation..., S. Bagster \& Sons, London and James Pott, New York, n.d., p.378.

32 Josephus, op.cit., p. 249 (see footnote 24).

33 Pseudo-Philo's Liber Antiquitatum Biblicarum, edited and with an introduction by GuIDo Kisch, University of Notre Dame Press, Notre Dame (Ind.) 1950; The Biblical Antiquities of Philo, now first translated from the old Latin Version by M.R.JAMEs, Macmillan, London/New York 1917.

34 Biblical Antiquities, p. 232. 
tablished tradition which may rest on accounts closer in time to the events described in the Old Testament and transmitted either orally or in writing. Certainly, choking sensations would not be inconsistent with the reported onset of Saul's disorder, particularly in view of the circumstances in which it first appeared. Saul's repudiation by Samuel was undoubtedly a very serious political blow, but the psychological impact on the king was devastating. Saul's behavior in his dramatic confrontation with Samuel reveals the dismay with which he heard the man who had anointed him now renounce him as unfit to rule Israel. "As Samuel turned to go away, Saul laid hold upon the skirt of his robe. ... Then he said, 'I have sinned; yet honor me now before the elders of my people and before Israel and return with me, that I may worship the Lord your God" ". ${ }^{35}$ Samuel agreed to this request, but immediately after Saul worshiped Samuel returned to Ramah and never saw him again.

Saul's harsh treatment of his actual or potential enemies is well documented. His command to slaughter the priests who sheltered David, and to exterminate the inhabitants of Nob where their shrine was located, his repeated attempts to kill David, and his murder of the Gibeonites, all indicate very clearly that Saul did not shrink from bloodshed. ${ }^{36}$ It is all the more significant, therefore, that the available sources give no hint of any action taken by Saul against Samuel following their break. Yet it seems implausible to assume that Saul harbored no resentment and hostility toward his erstwhile sponsor. The final breach with Samuel probably left Saul seething with conflicting emotions, overwhelmed with rage and humiliation, but these tensions could not easily be resolved. However much Saul may have wanted to rid himself of Samuel, the awesome power of his opponent probably compelled him to repress his desires. Perhaps he feared to take up a struggle against the mysterious divine power represented by Samuel, the power from which an outpouring of Spirit had filled his being and which had now departed from him. ${ }^{37}$ Such an attitude is suggested by the phrase, "the Lord your God", referring to the God of Samuel, used by Saul in his plea to Samuel to attend his worship and not to humiliate him before the

35 I Samuel 15: 27-30.

36 I Samuel 22: 6-19; II Samuel 21: 1-2.

37 Martin Buber, Werke (3 vols.), Lambert Schneider, Kosel 1964, vol. 2, pp. 804-905; R.Brinker, The Influence of Sanctuaries in Early Israel, Manchester University Press, Manchester 1946, pp.253-255. 
elders of Israel. The king realized the great need not to provoke the religious forces which governed his actions, even though the mouthpiece of this force, the channel of divine-human communication, was a hated enemy whom he might wish to destroy. This ambiguous psychological situation probably did not remain without consequence for Saul. Fear of Samuel's God, guilt at having provoked divine wrath, and his ambition to retain his kingdom very likely led Saul to repress his anger and resentment and not to take action against Samuel. However, this repression may unconsciously have led him to express his actual desires in a symbolic, distorted way through somatic symptoms. From this viewpoint it is at least plausible to suggest that the tradition of an evil spirit choking Saul may have been derived from an interpretation in contemporary terms of episodes of hysterical suffocation which he experienced, a condition now regarded as due to an unconscious rejection of aggressive fantasies and desires. Moreover, such somatic symptoms may subsequently be replaced wholly or in part by anxiety and depression associated with the conflict out of which they arose, a development which also appears consistent with Saul's case.

Unfortunately, however, we know nothing certain, and can only speculate and conjecture about the subjective aspect of Saul's condition. Nevertheless, we do know something specific about Saul's treatment, and the way in which his overt behavior was viewed and described. To these aspects we now turn.

\section{Music Charms Away the Evil Spirit}

Music had a prominent place in the life of ancient Israel, and Hebrew musicians because of their skill were highly esteemed not only by their compatriots but apparently also by foreigners. Thus, Sennacherib, the Assyrian king, considered the "male and female musicians" in the tribute sent to Nineveh by Hezekiah of Judah significant enough to mention in his account of the defeat of the Judean king and the capture of Jerusalem in 701 в. . . ${ }^{38}$ Moreover, the effect of music on the emotions was well-known,

38 James B. Pritchard (ed.), Ancient Near Eastern Texts Relating to the Old Testament, second edition, Princeton University Press, Princeton (N.J.) 1955, p. 288; S.B. FinesinGER, Musical Instruments in the Old Testament, Hebrew Union College Annual 3 (1926) 21-75; O.R. Sellers, Musical Instruments of Israel, in The Biblical Archaeologist Reader, edited by C.Ernest Wright and David Noel Freedman, Anchor Books-Doubleday, Garden City (N.Y.) 1961, pp. 81-94. 
and the use of singing and instrumental music to create or to intensify emotional experiences is fully documented by numerous references in the Old Testament.

Following the Egyptian defeat at the Red Sea, Miriam took a timbrel in her hand to lead the women of Israel in a song and dance of victory ${ }^{39}$ Deborah the prophetess also -celebrated the important victory of the Israelites over the Canaanite general Sisera with a song. ${ }^{40}$ Elisha called for a musician to help induce the prophetic trance in which he delivered the oracular message of the Lord. ${ }^{41}$ And when David brought the ark of God to Jerusalem he and the Israelites rejoiced before the Lord "with all their might, with songs and lyres and harps and tambourines and castanets and cymbals". ${ }^{42}$ Furthermore, the elaborate musical organization of the Temple described in I Chronicles may be an idealization, but it almost certainly rested on a historical basis probably developed by David himself. ${ }^{43}$

This musical tradition undoubtedly provided in part the context for the therapeutic counsel given to Saul when his disorder first became apparent, namely, "to seek out a man who is skilful in playing the lyre; and when the evil spirit from God is upon you, he will play it and you will be well". However, the musical tradition does not explain the choice of this therapy. To deal with this problem, the version given by Josephus serves as a useful point of departure. According to his account, Saul's physicians ordered "search to be made for one with power to charm away spirits and to play upon the harp". ${ }^{44}$ This statement is based on contemporary ideas and practices. Thus, Pseudo-Philo cites the psalm which David composed and sang to Saul in order to drive away the evil spirit. ${ }^{45}$ Josephus refers to Solomon's reputed skill in casting out demons, and mentions that he "left behind forms of exorcism with which those possessed by demons drive them out, never to return". In this connection, he remarks that "this kind of cure is of very great power among us to this day"; and relates that he had seen "a certain

\footnotetext{
39 Exodus 15: 20-21.

40 Judges 5 : 1-31.

412 Kings 3: 15.

42 Samuel 6: 5.

43 I Chronicles 25: 1, 6-8; Albright, Archeology and the Religion of Israel, pp.125-129 (see above n.13).

${ }^{44}$ I Samuel 16: 16; Josephus, op.cit., p. 249.

45 Biblical Antiquities of Philo, pp.232-233.
} 
Eleazar, a countryman of mine, in the presence of Vespasian, his sons, tribunes and a number of other soldiers, free men possessed by demons ...". ${ }^{46}$ Possession by unclean or evil spirits and demons is also a frequent cause of illness, especially of madness, in the New Testament, and Jesus performed a number of cures by casting out such spirits. ${ }^{47}$

Belief in intrusive evil spirits is nearly world-wide, and invasion by such forces has been a common explanation of abnormal behavior of various kinds from the earliest times. ${ }^{48}$ Frequent examples of this belief occur in the literatures of Egypt, Babylonia and Assyria, and it was widespread throughout the ancient Mediterranean-Near East area. ${ }^{49}$ The popular religion of Israel also had a belief in the existence of invasive spirits, even though only a few traces remain in the Old Testament. As the Yahwist religion of the Bible developed, ancient materials were recast in its mold. Thus, the evil spirit from the Lord that tormented Saul was probably originally a separate invasive force, demonic in nature, which came to be regarded as an extension of Yahweh. ${ }^{50}$

The therapeutic use of vocal and instrumental music can be understood within this context. Treatment for illness caused by intrusive spirits is basically simple: remove or mollify the cause. For this purpose various means may be employed including the incantatory power of music. From the earliest times to the present primitive healers have used charms and spells that were sung. Homer tells how the sons of Autolycus cared for Odysseus when he was slashed by a boar during a hunt, and how they stilled the bleeding with a chanted spell (epaiode). ${ }^{51}$ In treating illness, modern shamans like their ancient predecessors use vocal and instrumental

46 Josephus, op.cit., p. 595; Louis Ginzberg, The Legends of the Jews (6 vols.), Jewish Publication Society of America, Philadelphia, vol.IV, 1954, pp.149-153; vol.VI, 1946, p.291, notes 48 and 49.

47 Matthew 8: 28-34; Mark 5: 1-13; Luke 8: 2, 26-33.

48 Edward Norbeck, Religion in Primitive Society, Harper and Bros., New York 1961, p. 215.

49 The Legend of the Possessed Princess, in Ancient Near Eastern Texts (footnotes 38), pp.29-31; Erwin Rohde, Psyche, Seelencult und Unsterblichkeitsglaube der Griechen, fünfte und sechste Auflage (2vols.), J.C.B.Mohr (Paul Siebeck), Tübingen 1910, vol.2, p. 26 , note 1 ; pp. $413-414$.

50 KaufmanN, op.cit., pp.122-149; RoBinson, op.cit., p.179.

${ }^{51}$ Homer, Odyssey XIX, 455-460. See also The Odyssey of Homer, translated by EnNIs Rees, Random House, New York 1960, p.326. 
music to deal with the spirits involved in the case. ${ }^{52}$ As Chadwick puts it, music is "the language of spirits" and is employed to summon or to banish them. ${ }^{53}$ According to Pseudo-Philo, the psalm which David composed had the power when sung by him to mollify the evil spirit and to make him depart. At present, there is no way of knowing whether David's playing had as its purpose to appease or to expel the evil spirit, but that he played before Saul with one or both of these motives is very likely.

Clearly, the treatment which Saul received must be interpreted from two different viewpoints. From our angle of vision, it is highly probable that whatever relief Saul obtained because of David's playing was a psychotherapeutic effect. Indeed, psychic treatment was not unknown in antiquity, and rabbis of the post-exilic period occasionally permitted the use of incantations to set a patient's mind at ease. ${ }^{54}$ The effect of music on the emotions was also known and was used in cases of mental disorder. ${ }^{55}$ For Saul, David and their contemporaries, however, for these men who lived almost three thousand years ago, treatment by singing and playing an instrument was employed within a very different framework of perception and action. Our view of their thought and behavior is obscured because of the fragmentary and often ambiguous nature of the evidence, which is therefore difficult to interpret. Nonetheless, it is clear that their behavior was governed by belief in the reality of supernatural forces which controlled their actions. Thus, the full significance of the mode of treatment proposed by Saul's counsellors can be grasped only by endeavoring to understand it from their point of view. In these terms it seems very likely that David's playing was part of a therapeutic incantation which was repeated from time to time as the need arose.

52 Owen Lattimore, Studies in Frontier History, Collected Papers 1929-58, Oxford University Press, London 1962, pp.379-392; Julius Berendes, Musik und Medizin, Ciba-Z.9, No. 100 (1961) 3314-3319.

53 Nora K. Chadwick, The Spiritual Ideas and Experiences of the Taters of Central Asia, J.Roy. Anthropol.Inst.66 (1936) 291-329 (see p.297).

54 Joshua Trachtenberg, Jewish Magic and Superstition. A Study in Folk Religion, Behrman's Jewish Book House, New York 1939, p.196.

55 Beat Boehm, Heilende Musik im griechischen Altertum, Z.Psychother.Med.Psychol.7 (1957) 132-151; Joseph Schumacher, Musik als Heilfaktor bei den Pythagoreern im Licht ihrer naturphilosophischen Anschauungen, in Musik in der Medizin, Beiträge zur Musiktherapie, herausgegeben von Dr.med. H.R.TeIRICH, Verlag Gustav Fischer, Stuttgart 1958, pp.1-16; Eric Werner and Isaiah Sonne, The Philosophy and Theory of Music in Judaeo-Arabic Literature, Hebrew Union College Annual 16 (1941) 251-319; 17 (1942-1943) 511-572 (see particularly vol.16, pp. 262-263, 273-288. 